Agro-Science Journal of Tropical Agriculture, Food, Environment and Extension Volume 8 Number 1 January 2009 pp. 24-30

ISSN 1119-7455

\title{
HYDROCARBON DEGRADATION IN POULTRY DROPPINGS AND CASSAVA PEELS-AMENDED TYPIC PALEUSTULTS IN SOUTHEASTERN NIGERIA.
}

\author{
Jidere, C. M. and Akamigbo, F.O.R. \\ Department of Soil Science, University of Nigeria, Nsukka, Enugu State, Nigeria.
}

\begin{abstract}
This greenhouse study was aimed at determining the potentials of poultry droppings (PD) and cassava peels (CP) for nutrient-enhanced biodegradation of petroleum hydrocarbon (THC) in a well drained Typic Paleustults using the THC levels and degradation duration as remediation indices. The performance of the organic amendments was compared against the performance of NPK fertilizer. The soil was contaminated with crude oil at the rate of $50 \mathrm{t} / \mathrm{ha}$, after which the soil amendments were applied in single and combined forms (25 t PD/ha + 25 t CP/ha, and 50 t PD/ha + 50 t CP/ha), with the control as 0 t/ha (without soil amendment). Soil samples were collected from the contaminated soils at 14, 45, 76, 131 and 201 days after the application of the amendments respectively. There were significant $(P=0.05)$ effects of the amendments and rates of application on the THC concentrations. A comparison of the effects of PD, CP, NKP fertilizer and PD + CP on the THC concentrations at 201 days showed decrease in the contaminant concentrations in the order: NPK fertilizer < $P D<C P+P D<C P<C o n t r o l$. The percent THC degradation at 201 days for $50 t C P$ and $100 t$ CP were $23 \%$ and $24 \%$ respectively, while that of $50 t P D$ and $100 t P D$ were $34 \%$ and $36 \%$ respectively. For soils treated with NPK fertilizer and CP + PD, the percent THC degradation was $40 \%$ and $41 \%$ for $50 t$ NPK and $100 t$ NPK fertilizers respectively, and $26 \%$ and $31 \%$ for $25 t C P+25 t P D$ and $50 t C P+50 t P D$ respectively. The time required to completely degrade the THC in the soil followed the same trend. Although PD showed great potential for THC degradation, it will take less time to achieve $100 \%$ degradation of THC in NPK fertilizeramended soil when compared with the other nutrient supplements.
\end{abstract}

Keywords: Biodegradation; Organic amendments; Soil contamination; Total hydrocarbon

\section{INTRODUCTION}

Since oil pipeline network is widespread across almost all the agro-ecological zones in Nigeria, oil spillages are no longer restricted to the oilproducing zones. Incidences of crude oil spills at nonoil producing zones, and the consequent contamination of terrestrial ecosystems abound. Accidental spillages due to oil well blow-outs or pipeline leakages; and continuous low level inputs such as natural seepage from oil reservoirs in seabeds, the discharge of oil containing effluent from oil terminals and quality control centers and discharges from boat traffic are the main types of petroleum leakage into the environment (Isinguzo and Odu, 1983). Under natural environment, crude oil pollution resulted in increased percentage organic carbon and decreased phosphorus (Ogboghodo et al., 2004). These manifest in the alteration of the ecological equilibrium such as change in biodiversity and soil biomass, and alteration of soil physico-chemical status, with the consequent abandonment of such lands; leading to reduction of productive land resource base available to rural farmers in such zones.
The undesirable ecological and socioeconomic effects associated with oil spills have led to the development of remediation techniques aimed at reducing the adverse effects of oil in the environment. Such technologies include strategies designed to stimulate indigenous subsurface hydrocarbondegrading bacteria (Thomas et al., 1987, Lee et al., 1988), air stripping funnel and gate systems and vapor extraction systems which are of a typically high cost or have limited application (Curtis and Lammey, 1988), and require monitoring and control for optimum performance, and do not usually result in a complete destruction of the contaminant (Yerushalmi et al., 2003). Due to continual fiscal constraints and adverse effect on the environment, an environmentally friendly approach to effectively mitigate or remediate hydrocarbon releases into the environment, becomes inevitable. Biological degradation of contaminant or pollutant in the environment has been described as a proven method of remediating petroleumcontaminated soils, and soils contaminated by many other organic chemicals (Marc St- Cyr et al., 1992; Jørgensen et al., 2000). Although this technique is a site-specific process and its efficiency may be limited by microbiological and physico-chemical conditions 
in the soil (Yerushalmi et al., 2003), bioremediation is widely accepted as environmentally friendly, economically and politically viable (Rhykerd et al., 1999).

Bioremediation uses naturally occurring organisms to clean up polluted sites by transforming toxic and other undesirable materials into more benign or volatile substances. In order to enhance the natural degradation process, sufficient nitrogen and phosphorus are required to balance the available hydrocarbons in order for microbial growth and hydrocarbon reduction to occur (Mark and Jeffery, 1991). Viñas et al., (2005) attributed a remarkable shift in the composition of bacterial community to both the biodegradation processes and the addition of nutrient.

Cassava peels $(\mathrm{CP})$ derived from the tropical root crop cassava (Manihot sp.) and poultry droppings (PD) have been used as amendments on degraded soils in southeastern Nigeria (Agbim, 1985; Mbagwu, 1992), and for nutrient-enhanced biodegradation of hydrocarbon in crude oil-contaminated wetland soil (Akamigbo and Jidere, 2002). So far, there is limited information on the potentials of these waste materials for nutrient-enhanced biodegradation of hydrocarbon in Typic Paleustults, of southeastern Nigeria. This information will be useful in rehabilitating abandoned land resource base available for crop production. The objective of this greenhouse study was therefore to compare the potentials of $\mathrm{PD}, \mathrm{CP}$ and inorganic fertilizer for nutrient enhanced-biodegradation of hydrocarbons in crude oil-contaminated Typic Paleustults using hydrocarbon level and projected remediation duration as remediation index.

\section{MATERIALS AND METHODS Location}

The study was carried out at the Faculty of Agriculture Farm, University of Nigeria, Nsukka, using topsoil $(0-15 \mathrm{~cm})$ from the Nkpologu soil series, classified as Typic Paleustults (Soil Taxonomy, 1999), and Ferric Acrisols (FAO-UNESCO, 1988). The soils are derived from false-bedded sandstones. The area is located by Latitudes $06^{\circ} 30^{\prime} \mathrm{N}$ and Longitudes $07^{\circ} 10^{\prime} \mathrm{E}$, has an elevation of about $400 \mathrm{~m}$ above mean sea level and slopes of between $2-4 \%$. It is characterized by bimodal rainfall patterns with wet and dry seasons lasting from April to October and November to March respectively (Obi, 1982). The average total annual rainfall of the area is $1600 \mathrm{~mm}$ and the vegetation is a derived savannah. The mean monthly temperature varies between $25^{\circ} \mathrm{C}$ and $32^{\circ} \mathrm{C}$.

\section{Materials}

The physical characteristics of the soils prior to the start of the study are presented in Table 1 . The particle size distribution shows that the soil is predominated by sand fraction $(80 \%)$ while the clay and silt fractions are $15 \%$ and $5 \%$ respectively, thereby placing the soil in a textural class of Sandy Loam. With the bulk density, gravimetric water retention at saturation and total porosity of $1.69 \mathrm{~g} / \mathrm{cm}^{3}$,
$21 \%$ and $36 \%$ respectively, the soil is well drained and aerated all year round.

The crude oil used for the study was Nigerian Bonny Light obtained from Shell Petroleum Development Company (SPDC) Ltd Port Harcourt, Nigeria. Table 2 shows the chemical characteristics of the soil before and after contamination with crude oil.

The poultry droppings used for the study was collected from the battery cage poultry farm of University of Nigeria, Nsukka, while the cassava peels were obtained from local cassava processing centers. The NPK fertilizer 15:15:15 was sourced from the local market. The chemical characteristics of these soil amendments are shown in Table 3.

\section{Greenhouse study}

The topsoil $(0-15 \mathrm{~cm})$, poultry droppings (PD) and cassava peels (CP) were air-dried, ground and sieved to pass through $2 \mathrm{~mm}$ sieve. The soil was contaminated with crude oil at the rate of $50 \mathrm{t} / \mathrm{ha}$, after which the soil amendments were applied in single form (50 t PD/ha, $100 \mathrm{t} \mathrm{PD/ha,} 50 \mathrm{t} \mathrm{CP/ha,} 100 \mathrm{t}$ $\mathrm{CP} / \mathrm{ha}, 50 \mathrm{t} \mathrm{NPK} / \mathrm{ha}$ and $100 \mathrm{t} \mathrm{NPK} / \mathrm{ha}$ ) and combined forms (25 t PD/ha $+25 \mathrm{t} \mathrm{CP} / \mathrm{ha}$, and $50 \mathrm{t} \mathrm{PD/ha}+50 \mathrm{t}$ $\mathrm{CP} / \mathrm{ha}$ ), with the control as $0 \mathrm{t} / \mathrm{ha}$ (without soil amendment). The amendments were mixed thoroughly with $3 \mathrm{~kg}$ of the polluted soils. Each amendment was applied after one week of contamination and replicated three times, giving rise to twenty seven pots. The soils were placed in ceramic pots with drainage holes at the base, plugged with cotton wool to retain the soil. The pots were arranged in a completely randomized design in the greenhouse and allowed to stand for 201 days. The pots were watered to field capacity once in a week, while soil samples were taken from the surface of the pots at 14 , $45,76,131$ and 201 days after the application of the amendments resnectivelv

Jidere, C. M. and Akamigbo, F.O.R.

\section{Laboratory analyses}

The chemical properties of the contaminated soil and non-contaminated soil, $\mathrm{CP}$, and PD were determined. The soil samples were air-dried, ground, sieved to pass $2 \mathrm{~mm}$ sieve and analyzed for the following properties: organic carbon by Walkley and Black analytical method as described by Nelson and Sommes (1982); total nitrogen by macro Kjeldahl method as described by Bremner and Mulvaney (1982); and available phosphorus by Bray II method as described Olsen and Sommers (1982); total hydrocarbon, using Infrared Spectrophotometer. The cation exchange capacity and exchangeable base was determined using ammonium acetate as extracting solution (Thomas, 1982), while the exchangeable acidity was determined according to the method of Mclean (1982). Soil physical properties determined were particle size distribution, using hydrometer method as described by Gee and Bauder (1986), and bulk density, using Blake and Hartge (1986). Total porosity, was calculated from the bulk density using an assumed particle density of $2.65 \mathrm{~g} / \mathrm{cm} 3$, from $\mathrm{f}=$ 100(1 - Dry bulk density/Particle density), where $\mathrm{f}=$ Total porosity. This method was described by 
Vomocil (1965). The computation of percent hydrocarbon saturation at 201 days, percent degradation and degradation rate respectively were carried out as follows;

Percent hydrocarbon saturation at 201 days = $\left(C_{201} \div C_{\text {initial }}\right) \times 100$

Percent hydrocarbon degradation = $100-\left[\left(C_{201} \div C_{\text {initial }}\right) \times 100\right]$

Time required for $100 \% \mathrm{HC}$ degradation (Year) $=$ $\left[\left(201\right.\right.$ days $\left.\left.\div \% C_{201}\right) \times 100\right] \div 365$ days

Degradation rate $=C_{\text {initial }}-C_{201} / T$

Where: $\quad \mathrm{C}_{201}=$ Hydrocarbon concentration at 201

days

$\mathrm{C}_{\text {initial }}=$ Hydrocarbon concentration at the

beginning of the study.

$\% \mathrm{C}_{201}=$ Percentage hydrocarbon degradation

at 201 days

$\mathrm{T}=$ Duration of study

\section{Data analysis}

Analysis of variance using GenStat

Discovery Edition 2 computer package was performed on the soil data to assess the effect of the nutrient supplements on hydrocarbon degradation. The mean differences were compared for statistical significance using Fisher's least significant differences of means (5\% level) as described by Obi (1986).

\section{RESULTS AND DISCUSSION}

The soil $\mathrm{pH}$ determined in both water and $\mathrm{KCl}$ was higher after the contamination with crude oil than before contamination (Table 2). Organic carbon was very high after contamination $(4.62 \%)$ relative to the value before contamination $(0.74 \%)$. Similar trend was observed in the total nitrogen, while the $\mathrm{C} / \mathrm{N}$ ratio of the soil before and after contamination was 14:1 and 33:1 respectively. The contamination of the soil with crude oil increased the total hydrocarbon of the soil from initial value of $10.6 \mathrm{mgkg}^{-1}$ to 3660.48 $\mathrm{mgkg}^{-1}$. The reverse was the case for phosphorus as the value dropped from $14 \mathrm{mgkg}^{-1}$ to $1.6 \mathrm{mgkg}^{-1}$ after contamination. Table 3 indicates that the poultry droppings contain organic matter of $13.60 \%$ while the values are $51.5 \%$ and $36.10 \%$ in cassava peels and PD $+\mathrm{CP}$ respectively. This trend was reversed in the nitrogen content of the amendments, thus resulting to a very wide $\mathrm{C} / \mathrm{N}$ ratio observed in the $\mathrm{CP}$ compared with the $\mathrm{PD}$ and $\mathrm{PD}+\mathrm{CP}$ respectively.

The organic carbon (OC) and total petroleum hydrocarbon (THC) concentrations are presented in Table 4 . The table showed very high concentrations of OC and THC in all the soils, especially at the first sampling date $\left(14^{\text {th }}\right.$ day of the study). High concentrations of OC and THC are indicators of soil contamination. This was deduced from the fact that hydrocarbon degradation, time required for $100 \% \mathrm{HC}$

the values of OC and THC increased after contamination with crude oil (Table 2). The contaminant (THC) was significantly $(\mathrm{P}<0.05)$ higher in the non-amended soil (control, 0 t/ha) relative to the amended soils throughout the duration of the study (Table 4). In addition, significantly higher concentration of $\mathrm{OC}$ was recorded in the control when compared with the amended soils. The higher concentrations of $\mathrm{OC}$ and $\mathrm{THC}$ in the control suggested relatively slow degradation of THC, probably due to poisoning of microbes, high chain hydrocarbons and/or lack of essential nutrient elements, occasioned by the absence of soil amendments. This was in line with the report of Zobell (1973) that bioremediation of crude oil in a natural ecosystem is relatively slow

\section{Table 1: Physical characteristics of the soil} used for the study

\begin{tabular}{ll}
\hline Parameter & Value \\
\hline Clay $(\%)$ & 15 \\
Silt $(\%)$ & 5 \\
Sand $(\%)$ & 80 \\
Textural Class & Sandy Loam \\
Bulk Density $\left(\mathrm{g} / \mathrm{cm}^{3}\right)$ & 1.69 \\
Total Porosity $(\%)$ & 36 \\
Water Retention $(\%)$ & 21 \\
Hydraulic Conductivity $(\mathrm{cm} / \mathrm{hr})$ & 16.50 \\
\hline
\end{tabular}

Table 2: Chemical characteristics of the soil before and after crude oil contamination

\begin{tabular}{|c|c|c|}
\hline Parameter & $\begin{array}{l}\text { Before } \\
\text { Contamination }\end{array}$ & $\begin{array}{l}\text { After } \\
\text { Contamination }\end{array}$ \\
\hline $\mathrm{pH}$ (water) & 4.2 & 4.7 \\
\hline $\mathrm{pH}(\mathrm{KCl})$ & 4.0 & 4.4 \\
\hline Organic Carbon (\%) & 0.74 & 4.62 \\
\hline Total N (\%) & 0.05 & 0.138 \\
\hline C/N Ratio & $14: 1$ & $33: 1$ \\
\hline $\mathrm{Ca}^{2+}(\mathrm{Cmol} / \mathrm{kg}$ Soil $)$ & 1.2 & 1.6 \\
\hline $\mathrm{Mg}^{2+}(\mathrm{Cmol} / \mathrm{kg}$ Soil $)$ & 0.2 & 0.2 \\
\hline $\mathrm{Na}^{+}(\mathrm{Cmol} / \mathrm{kg}$ Soil $)$ & 0.015 & 0.190 \\
\hline $\mathrm{K}^{+}(\mathrm{Cmol} / \mathrm{kg}$ Soil $)$ & 0.015 & 0.024 \\
\hline $\mathrm{CEC}$ (Cmol/kg Soil) & 6.4 & 9.6 \\
\hline $\mathrm{H}^{+}(\mathrm{Cmol} / \mathrm{kg}$ Soil $)$ & 0.4 & 0.8 \\
\hline $\mathrm{Al}^{3+}(\mathrm{Cmol} / \mathrm{kg}$ Soil $)$ & 1.8 & 3.6 \\
\hline Av. P $\left(\mathrm{mgkg}^{-1}\right)$ & 14 & 1.6 \\
\hline $\mathrm{THC}\left(\mathrm{mgkg}^{-1}\right)$ & 10.6 & 3660.48 \\
\hline
\end{tabular}

Table 3: Chemical Characteristics of the Amendments

\begin{tabular}{llll}
\hline Parameter & $\begin{array}{l}\text { Poultry Droppings } \\
(\mathrm{PD})\end{array}$ & $\begin{array}{l}\text { Cassava Peels } \\
(\mathrm{CP})\end{array}$ & $\begin{array}{l}\text { PD + CP } \\
(1: 1)\end{array}$ \\
\hline Organic Carbon (\%) & 13.60 & 51.5 & 36.10 \\
Total N (\%) & 3.80 & 0.36 & 0.60 \\
C/N Ratio & $4: 1$ & $143: 1$ & $60: 1$ \\
$\mathrm{Ca}^{2+}(\%)$ & 8.00 & 1.20 & 1.36 \\
$\mathrm{Mg}^{2+}(\%)$ & 1.92 & 0.72 & 0.96 \\
$\mathrm{Na}^{+}(\%)$ & 0.76 & 0.28 & 0.45 \\
$\mathrm{~K}^{+}(\%)$ & 0.76 & 0.70 & 1.20 \\
$\mathrm{P}\left(\mathrm{mgkg}^{-1}\right)$ & 7.16 & 0.88 & 0.166 \\
\hline
\end{tabular}


Table 4: Organic carbon and total petroleum hydrocarbon concentrations of crude oil contaminated soil after incorporation of soil amendments.

\begin{tabular}{|c|c|c|c|c|c|}
\hline Amendment & 14 Days & 45 Days & 76 Days & 131 Days & 201 Days \\
\hline \multicolumn{6}{|c|}{ Organic Carbon $(\%)$} \\
\hline 0 t Control & 6.43 & 5.81 & 5.53 & 5.18 & 4.21 \\
\hline 50 t CP & 5.18 & 5.14 & 5.46 & 4.46 & 4.42 \\
\hline 100 t CP & 5.19 & 5.16 & 5.33 & 4.32 & 3.87 \\
\hline 50 t PD & 5.61 & 5.44 & 5.02 & 4.22 & 3.61 \\
\hline 100 t PD & 5.58 & 5.26 & 5.02 & 4.07 & 3.41 \\
\hline 50 t NPK & 5.84 & 5.62 & 4.40 & 3.60 & 3.46 \\
\hline $100 \mathrm{t}$ NPK & 5.40 & 4.82 & 4.06 & 3.65 & 3.42 \\
\hline $25 \mathrm{t} \mathrm{CP}+25 \mathrm{PD}$ & 6.26 & 5.63 & 5.32 & 4.03 & 3.54 \\
\hline 50 t CP + $50 \mathrm{PD}$ & 6.05 & 5.51 & 5.28 & 4.29 & 3.46 \\
\hline Mean & 5.72 & 5.38 & 5.05 & 4.20 & 3.71 \\
\hline $\operatorname{LSD}_{(0.05)}$ & 0.103 & 0.194 & 0.056 & 0.166 & 0.151 \\
\hline \multicolumn{6}{|c|}{ Total petroleum hydrocarbon $\left(\mathrm{mgkg}^{-1}\right)$} \\
\hline 0 t Control & 3381.79 & 3265.35 & 3195.1 & 3046.4 & 3012.7 \\
\hline $50 \mathrm{t} \mathrm{CP}$ & 3304.68 & 3226.48 & 3045.8 & 2947.1 & 2809.1 \\
\hline 100 t CP & 3266.46 & 3185.45 & 2828.1 & 2861.8 & 2790.1 \\
\hline 50 t PD & 3286.31 & 3110.33 & 2935.4 & 2688.8 & 2417.8 \\
\hline 100 t PD & 3209.70 & 3146.58 & 2804.2 & 2654.3 & 2358.9 \\
\hline $50 \mathrm{t}$ NPK & 3291.62 & 3161.14 & 2552.4 & 2403.0 & 2185.2 \\
\hline 100 t NPK & 2901.33 & 2876.58 & 2454.2 & 2305.5 & 2160.3 \\
\hline $25 \mathrm{t} \mathrm{CP}+25 \mathrm{PD}$ & 3296.22 & 3134.50 & 2924.4 & 2824.3 & 2691.4 \\
\hline 50 t $C P+50 P D$ & 3174.72 & 3098.23 & 2884.4 & 2736.4 & 2553.7 \\
\hline Mean & 3234.76 & 3133.85 & 2847.1 & 2718.6 & 2553.2 \\
\hline $\operatorname{LSD}_{(0.05)}$ & 7.325 & 5.076 & 15.07 & 12.68 & 9.97 \\
\hline
\end{tabular}

Table 5: THC degradation (\%), degradation rate and time required for complete THC

\begin{tabular}{llll}
\multicolumn{2}{c}{ degradation. } & \\
\hline Amendment & $\begin{array}{l}\text { THC Saturation } \\
(\%)\end{array}$ & $\begin{array}{l}\text { Time required for 100\% THC } \\
\text { degradation (Year.) }\end{array}$ & $\begin{array}{l}\text { THC Degradation Rate } \\
\text { ( } \text { mgkg }^{-1} / \text { day) }\end{array}$ \\
\hline 0 t Control & 82 & 3.1 & 3.2 \\
50 t CP & 77 & 2.4 & 4.2 \\
100 t CP & 76 & 2.3 & 4.3 \\
50 t PD & 66 & 1.6 & 6.2 \\
100 t PD & 64 & 1.5 & 6.5 \\
50 t NPK & 60 & 1.4 & 7.3 \\
100 t NPK & 59 & 1.3 & 7.5 \\
25 t CP + 25 PD & 74 & 2.1 & 4.8 \\
50 t CP + 50 PD & 69 & 1.8 & 5.5 \\
Mean $_{\text {LSD }}$ & $69.05)$ & 1.94 & 5.5 \\
& 1.72 & 1.72 & 1.72 \\
\hline
\end{tabular}

The addition of nutrient supplements is aimed at providing the nutrient elements required for microbial degradation of THC. The least percent THC degradation (18\%) was observed in the control (without nutrient supplement) (Fig. 1). The percent THC degradation at 201 days for $50 \mathrm{t} \mathrm{CP}$ and $100 \mathrm{t}$ CP were $23 \%$ and $24 \%$ respectively, while that of 50 t PD and 100t PD were $34 \%$ and $36 \%$ respectively. For soils treated with NPK fertilizer and mixture of $\mathrm{CP}+\mathrm{PD}$, the percent THC degradation was $40 \%$ and
$41 \%$ for $50 \mathrm{t}$ NPK and $100 \mathrm{t}$ NPK fertilizers respectively, and $26 \%$ and $31 \%$ for $25 \mathrm{t} \mathrm{CP}+25 \mathrm{t} \mathrm{PD}$ and $50 \mathrm{t} \mathrm{CP}+50 \mathrm{t} \mathrm{PD}$ respectively. The percent $\mathrm{THC}$ degradation was significantly $(\mathrm{P}=0.05)$ influenced by the application of nutrient supplements. Roger et al., (1993) asserted that the logic of applying fertilizers as the bioremediation strategy was that under pre-spill conditions, crude oil degrading bacteria was limited by the availability of oil as a carbon source. 


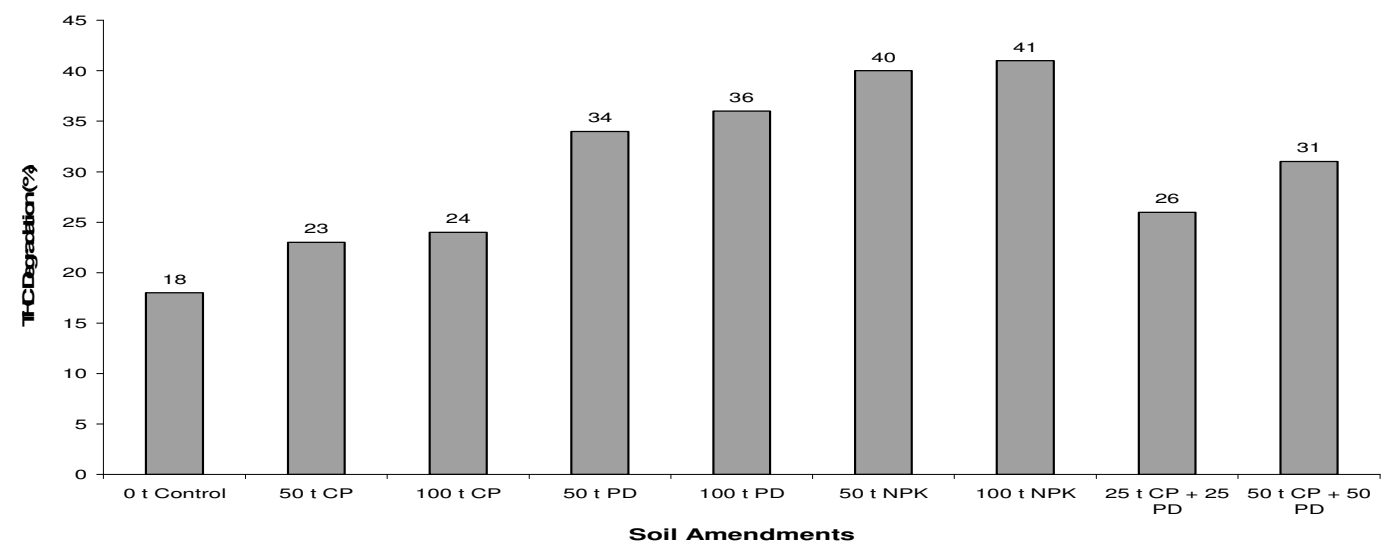

Fig. 1: Percent THC Degradation at 201 days after application of the amendments

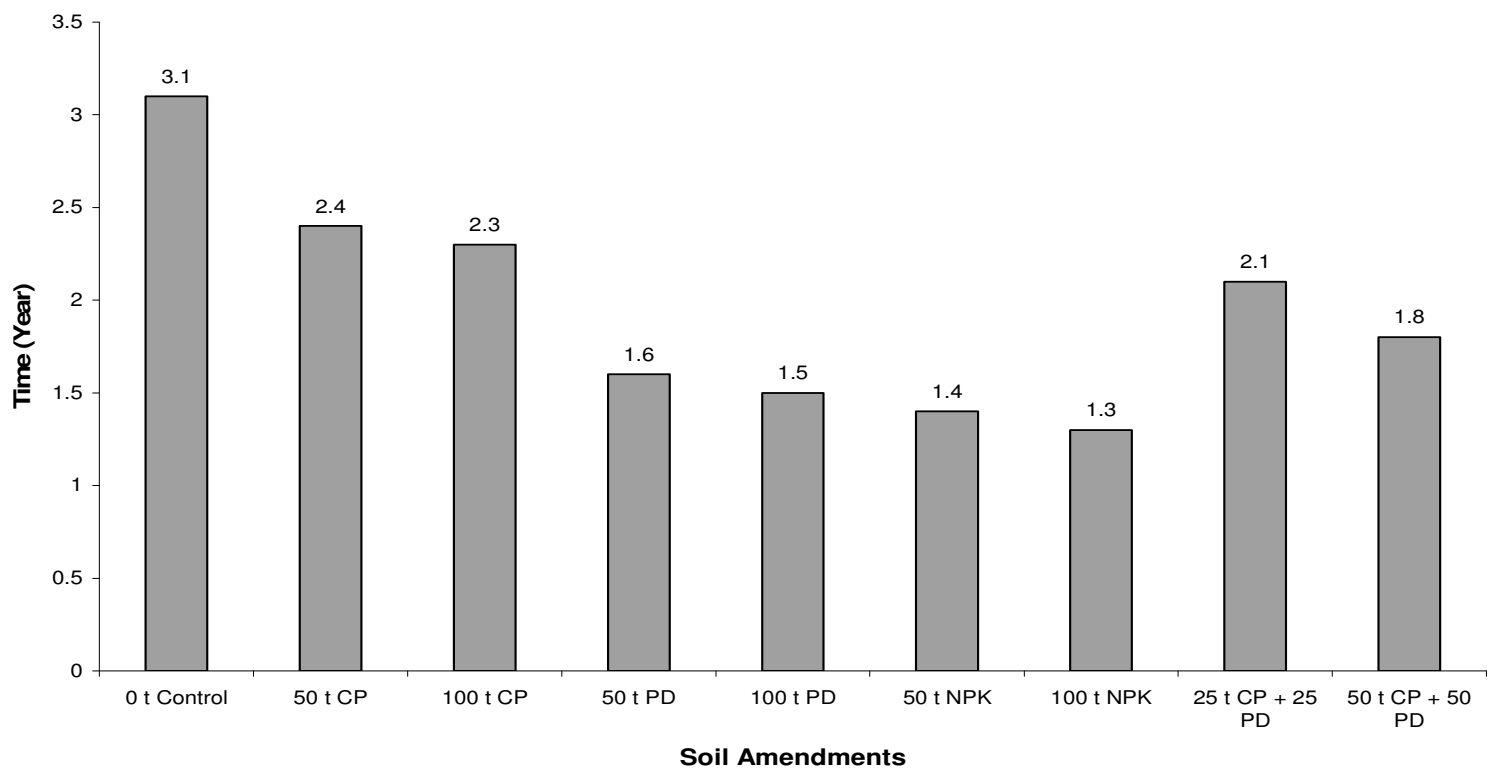

Fig. 2: Effect of the amendments on the time required for complete degradation of THC

The difference in the effect of the amendments on the THC degradation could be attributed to the variation in the potentials of the amendments to supply the essential nutrient elements for THC degradation. Indeed, the ability to supply the nitrogen, phosphorus and potassium varied with soil amendment (Table 3). Sufficient nitrogen and phosphorus are required to balance the available hydrocarbons in order for microbial growth and hydrocarbon reduction to occur (Mark and Jeffery, 1991). A comparison of the effect of PD, CP, NPK fertilizer and mixture of $\mathrm{PD}$ and $\mathrm{CP}$ on the THC concentrations showed that the concentration of the contaminant decreased in the order: NPK fertilizer < $\mathrm{PD}<\mathrm{CP}+\mathrm{PD}<\mathrm{CP}<$ Control (Table 4). The significantly $(\mathrm{P}=0.05)$ low THC level at 201 days observed in the NPK fertilizer-amended soil relative to the other soil amendments could be explained by the fact that NPK fertilizer was able to supply, in readily utilizable form, the essential nutrients required for THC degradation. Odu (1981) reported that lack of sources of readily utilizable nitrogen and phosphorus might limit growth of micro organisms and hence crude oil degradation in soils.

The THC level was significantly lower in the PD amended soil relative to the other organic amendments (Table 4). Similar result was reported by Adesodun and Mbagwu (2007) in the study of effect of some organic wastes on oil polluted soil. This could be attributed to quick net nitrogen mineralization of $\mathrm{PD}$ due to its narrow $\mathrm{C} / \mathrm{N}$ ratio and the variations in the nutrient element composition of the amendments (Table 3). Organic matter with $\mathrm{C} / \mathrm{N}$ ratios wider than 30/1 decomposes slowly because they lack sufficient nitrogen for microbes to increase in population (Miller and Donahue 1992). With a wide C/N ratio of 143:1, and low NPK levels, the sole application of CP showed less potential to support microbes for degradation of THC (Table 3). However, the addition of $\mathrm{PD}$ to $\mathrm{CP}$ narrowed down the $\mathrm{C} / \mathrm{N}$ ratio of the mixture (PD + CP) to 60:1, and improved its potential as nutrient supplement for microbial degradation of 
THC. Consequently, the potentials of organic material for nutrient-enhanced THC degradation are enhanced by narrow $\mathrm{C} / \mathrm{N}$ ratio.

Although PD showed great potential for THC degradation, however, Table 5 showed that it will take less time to achieve $100 \%$ degradation of THC in NPK fertilizer-amended soil when compared with the other amendments. The time required to completely degrade the THC in the soil is in the order: NPK fertilizer $<\mathrm{PD}<\mathrm{CP}+\mathrm{PD}<\mathrm{CP}<$ Control (Fig 2). While the highest THC degradation rate (7.5 $\mathrm{ppm}$ /day) was recorded in the $100 \mathrm{t}$ NKP fertilizeramended soils, the least degradation rate (3.2 $\mathrm{ppm} /$ day) was obtained in the control (Table 5), implying that it would take twice more time to degrade equivalent amount of THC in non-amended soil. Similarly, a comparison of the THC degradation rate in the organic waste-amended soil showed that the THC degradation rate was faster in the PD amended soil.

Total hydrocarbon concentration was significantly higher in lower doses of the nutrient supplement when compared with the higher rates of amendment application (Table 4). Similarly, the THC degradation was significantly higher in soils treated with higher doses of the nutrient supplements, thus implying that the percent THC degradation increases with increase in the rate of application of the nutrient supplements until an equilibrium is achieved.

\section{CONCLUSION}

This study was aimed at assessing the potentials of locally available organic wastes (poultry droppings and cassava peels), as an alternative to expensive inorganic nutrient supplements for remediation of crude oil contaminated soil. Using the THC level and degradation duration as remediation index, the study indicated that the application of the organic wastes to crude oil contaminated soil reduced the level of THC in the soil. The result of the experiment indicated that the chemical composition of the soil amendments and the application rates of the amendment are vital to the microbial degradation of petroleum hydrocarbon in soil. Although NPK fertilizer performed better in terms of THC degradation, PD showed high potentials for remediation of crude oil contaminated soil as the THC degradation rate in NPK fertilizer-amended soil was highly comparable to that of PD-amended soil. Addition of PD to $\mathrm{CP}$ improved the potentials of $\mathrm{CP}$ for the degradation of the contaminant and reduced the degradation duration. Therefore, the time required for complete degradation of the contaminant was less in NPK fertilizer-amended soil than the organic wastes-amended soil. The potentials of the nutrient supplements for THC degradation was in the following order: $\mathrm{NPK}>\mathrm{PD}>\mathrm{PD}+\mathrm{CP}>\mathrm{CP}>$ Control. However, based on environmental friendliness, the PD should be preferred to the NPK amendment.

\section{REFERENCES}

Agbim, N.N. 1985. Potentials of cassava peels as soil amendments: II Field evaluation. J. Eniron. Qual., 14: 411-415.

Akamigbo, F.O.R. and C.M. Jidere (2002). CarbonNitrogen dynamics in organic wastes amended-crude oil polluted wetland soil. Agro-Science Journal of Tropical Agriculture, Food, Environment and Extension. 3: 20 - 26.

Blake, G.R. and Hartge, K.H. (1986) Bulk density: In Klute, A. (Ed) Methods of Soil Analysis. Part I Physical and

Mineralogical Methods. ASA, No 9. Madison, Wisconsin pp 365 - 375.

Bremner, J.M. and Mulvaney, G.S. (1982) Nitrogen total: In: Page Miller, R.H. and Keeny, D.R. (eds.) Methods of Soil Analysis. American Society of Agronomy No 9, Madison, W.I. pp. $595-624$.

Curtis, F. and Lammey, J. 1998. Intrinsic Remediation of a Diesel Fuel Plume in Groose Bay, Labrador, Canada. Enviro. Pollu. 103: 203-210

Gee, G.N. and Bauder, J.W. 1986. Particle size analysis. In: Methods of soil analysis. Part I Klute, A. (Ed.) Am. Soc. Of Agron and Soil Sci. of Am. Madison W.I. pp. 91-100.

FAO/UNESCO. 1988. Soil map of the world. Revised Legend. FAO, Rome.

Isinguzo, S. N. and Odu, C.T. I. 1983. Oil Spillage and the use of Mutant Organisms for Enhanced Biodegradation. The Petroleum Industry and the Nigerian Environmental Proceedings of 1983 International Seminar. pp 132.

Jørgensen, K. S., Puustinen, J. and Suortti, A. M., 2000. Bioremediation of petroleum hydrocarbon-contaminated soil by composting in biopiles. Environmental Pollution. Volume 107, Issue 2, pp. 245-254

Lee, M.D; Thomas, J.M; Borden, R.C, Bedient, P.B; Wilson, J. T. and Ward, C.H. 1988. Bioremediation of aquifers contaminated with organic compounds. Critical Reviews of Environmental Control. 18: 29-89.

Marc St-Cry, Nelson, C.H and Hawke, C.T. 1992. Bioremediation treats contaminated soils in Canadian Winter. Oil and Gas Journal. pp. 68-72.

Mark A.J. and Jeffrey, H.G. 1991. In-situ Comparison of bioremediation methods for a number of residual fuel spill in Lee County, Florida. Proceedings of the 1991 Oil Spill Conference, American Petroleum Institute, Washington D.C. pp. 533-530.

Mclean, E.O. 1982. Aluminum. In: Methods of Soil Analysis. Black, C. A. (ed). Am. Agron No 9. Part 2. Madison, Wisconsin pp 978-998.

Mbagwu, J.S.C. 1992. Improving the productivity of a degraded Ultisol in Nigeria using Organic and Inorganic amendments. Part 2: Changes 
in physical properties. Bioresource Technology. 42:167-175.

Miller, R.W. and Donahue, R.L. (1992) Soils: An Introduction to Soils and Plant Growth. $6^{\text {th }}$ ed. Prentice-Hall of India Private Ltd. New Delhi. Pp. 188-189.

Nelson, D.N, and Sommers, L.E. (1982) Total organic carbon and organic matter: In methods of soil analysis Part II. Page, A.L., Miller, R.H. and Keeny, D.R. (eds.) American Society of Agronomy and Soil Sci. Soc. Of Am. Madison W.I. pp. 539 - 579.

Obi, I. U. 1986. Statistical Methods of Detecting Differences between Treatment Means. SNAAP Press Ltd, Enugu, Nigeria. 45pp.

Obi, M.E. 1982. Run-off and soil loss from an oxisol in southeastern Nigeria under various management practices. Agricultural Water Management 5. pp. 193-203.

Odu, C.T.I. 1981. Nitrogen Accretion in Oil Polluted Soils. In: Current Perspectives in Nitrogen Fixation. A.H. Gikson and W. Newton (Eds.) Australian Academy of Sci. Camerra.

Ogboghodo, A., E. K. Iruaga, I. O. Osemwota and J. U. Chokor., 2004. An assessment of the effects of crude oil pollution on soil properties, germination and growth of maize (Zea Mays) using two crude types - Forcados Light and Escravos Light. Environmental Monitoring and Assessment. 96: 143-152

Oleson, S.R. and Sommers, L.E. 1982. Phosphorus. In: Page, A.L., Miller, R.H. and Keeny, D.R. (Eds.). Methods of Soil Analysis. Part II. $2^{\text {nd }}$ ed. Am. Soc. Of Agron. Inc., Madison W.I. pp. $15-72$.

Roger, C.P., Richard, E.B., Graham, N.G., Copper, E.H., Matthew, J.G., Lute, R.G., David, L.E., Vera Misak-Bernero, Senius, J.D., Keim, L.G., Russell, R.C. and Hinton, S. 1993. The effect of bioremediation on the microbial population of oiled beaches in Prince William Sound, Alaska 1993 Oil Spill Conference Proceedings. 469-475.
Rhykerd, R.L., Crews, B. McInnes, K.J. and Weaver, R.W. 1999. Impact of bulking agent, forced aeration and tillage on remediation of oilContaminated Soil. Bioresearch Tech. 67:279-285.

Soil Survey Staff. 1999. Soil Taxonomy: A basic system of soil classification for making and interpreting soil survey. Soil Conservation Service, USDA, Washington DC

Thomas, G.W. 1982. Exchangeable cations. In: Page, A.L., Miller, R.H. and Keeny, D.R. (Eds.). Methods of Soil Analysis. Part II. $2^{\text {nd }}$ ed. Am. Soc. of Agron. Inc., Madison W..

Thomas, J. M, Lee, M.D; Bedient, P.B; Borden, R.C; Canter, L.W. and Ward, C.H. 1987. Leaking Underground Storage Tanks: Remediation. Robert S. Kerr Environmental Research Laboratory Publication, EPA 600/2-87/008. Cincinnati, OH: US Environmental. Protection Agency. Viñas M, Sabaté J, Espuny M.J, Solanas A.M., 2005. Bacterial community dynamics and polycyclic aromatic hydrocarbon degradation during bioremediation of heavily creosotecontaminated soil. Appl Environ Microbiol.; 71: 7008-18.

Vomocil, J.A. (1965) Porosity. In C.A. Black (ed) Methods of Soil Analysis, Part 1, American Society of Agronomy. 9: 299 - 314.

Yerushalmi, L., Rocheleau, S., Cimpooia, R., Sarrazin, M., Sunahara, G., Peisajovich, A., Leclair, G., and Guiot, S. 2003. Enhanced Biodegradation of Petroleum Hydrocarbons in Contaminated Soil. Bioremediation Journal 7: 37-51.

Zobell, C.E. 1973. Microbial-facilitated degradation of oil: Present Status, Problems and Perspectives. In the Microbial Degradation of Oil Pollutants, D.G. Ahearn and S.P. Meyers eds. Pub No. LSU-SG-73-01. Centre for Wetland Resources, Louisiana State University, Baton Rouge. p.3. 